\title{
KEMAMPUAN BERPIKIR KRITIS SISWA DALAM PEMBELAJARAN ILMU PENGETAHUAN ALAM KELAS IV
}

\author{
Jupriyanto \\ jupriyanto@unissula.ac.id \\ Universitas Islam Sultan Agung
}

\begin{abstract}
ABSTRAK
Fokus penelitian mengetahui pengaruh kemampuan berpikir kritis siswa pada mata pelajaran IPA dengan mengunakan model pembelajaran discovery learning. Desain yang digunakan dalam penelitian ini yaitu Quasi Ekperimental dengan Nonequivalent Control Group Desain. Pengumpulan data menggunakan pretest, posttest. Analisi data menggunakan uji T One Sampel Test untuk mengukur rata-rata kemampuan berpikir kritis. Hasil analisis data penelitian ini menunjukkan bahwa rata-rata kemampuan berpikir kritis IPA pada mata pelajaran IPA menggunakan model pembelajaran discovery learning mencapai kriteria minimum dengan hasil uji Sig (2-tailed) $=0,363>\alpha=0,05$.
\end{abstract}

Keywords: discovery learning, berpikir kritis, IPA SD

\section{PENDAHULUAN}

Sains atau pengetahuan alam di tingkat pendidikan dasar melibatkan semua aspek perkembangan siswa. Perkembangan yang dimaksudkan pada kemampuan siswa dalam melibatkan fisik atau psikhis siswa. Proses menyampaikan materi dengan detail sesuai tujuan pembelajaran dan tidak hanya melalui ceramah namun juga harus menunjukkan partisipasi siswa secara aktif. Pembelajaran yang melibatkan pengalaman langsung sangatlah diperlukan guna mendapatkan partisipasi aktif siswa. Proses ini sangat dibutuhkan terlebih dalam mata pelajaran IPA guna membentuk pola konkrit di dalam pembelajaran. Keterlibatan aktivitas siswa baik secara fisik ataupun mental akan mempengaruhi kebermaknaan dari pembelajaran yang mereka dapat. Pembelajaran haruslah dikemas sesuai dengan pengalaman keseharian yang dialami oleh siswa. Mengacu pada teori 
Bruner, pembelajaran bermakna oleh siswa ketika siswa mampu menguasai semua komponen materi yang dipelajari.

$$
\text { Kedekatan siswa dengan }
$$

pembelajaran dan materi yang diajarkan akan membuat mereka menjadi pembelajar aktif. Hal ini tidak dapat diwujudkan apabila dalam mengajar guru hanya menerepkan metode pembelajaran konvesional. Guru sebagai seorang pengajar, pembimbing dan pelatih menduduki peran penting di dalam proses pembelajaran. Bagaimana siswa dapat menerima materi dengan baik merupakan tugas yang harus selalu mereka pikirkan dan rencanakan dengan baik. Untuk itu, guru harus cerdas di dalam menyampaikan dan mengemas pembelajaran yang akan dilaksanakan. Dengan membuat suasana pembelajaran aktif dan tidak hanya berkutat pada metode yang itu itu saja akan menjadikan suasana pembelajaran lebih bernyawa.

Namun selama ini, guru banyak yang belum memadukan pembelajaran yang inovatif. Beberapa siswa masih tidak fokus ketika pembelajaran berlangsung sehingga tidak memperhatikan guru saat mengajar dimungkinkan karena pembelajaran yang berlangsung monoton dan membosankan. Guru hanya memposisikan siswa sebagai seorang pendengar. Mereka hanya menerima apa yang disampaikan oleh guru. Ketika guru memberikan stimulus siswa untuk bertanya, meraka hanya diam dan sesekali menjawab tetapi, dengan jawaban yang diungkapkan secara bersama-sama. Hal ini menunjukkan bahwa siswa tidak berani untuk mengungkapkan gagasan dan pendapat mereka sendiri. Mengkondisikan mereka untuk tidak biasa berpikir, mengeluarkan gagasan dan menjawab pertanyaan merupakan ciri dari pembelajaran yang biasa guru lakukan. Dengan begitu, kemampuan berpikir kritis siswa masih kurang dikembangkan. Jadi, perlu adanya pembiasaan berpikir kritis siswa dalam proses pembelajaran.

Berpikir merupakan suatu kemampuan yang membedakan manusia dengan makhluk lain. Berpikir kritis adalah kemampuan berpikir reflektif yang berfokus pada pola pengambilan keputusan apa yang harus diyakini dan harus dilakukan, Ennis (2011). Sedangkan Santrock (2009:11) 
mendefinisikan berpikir kritis meliputi berpikir secara reflektif dan produktif serta mengevaluasi bukti. Terdapat beberapa indikator dalam berpikir kritis diantaranya adalah (a) mengamati dan mempertimbangkan suatu laporan hasil observasi, (b) menentukan tindakan, (c) mengidentifikasi asumsi (d) Bertanya dan menjawab suatu penjelasan atau tantangan (e) menganalisis pertanyaan.

Hasil yang kurang memuaskan dapat ditengok dari data nilai Ulangan Akhir Semester (UAS) pada mata pelajaran IPA dengan nilai rata-rata UAS yang tidak mencapai KKM yang telah ditentukan pada kelas IV SDN Kalisari 03. KKM yang ditetapkan adalah 65 namun, perolehan rata-rata kelas IVa hanya 63,7 sedangkan pada kelas IVb perolehan rata-rata 64,6 . Hal ini semakin memperkuat bahwa rendahnya kemampuan berpikir di dalam mata pelajaran IPA kelas IV SDN Kalisari 03.

Pendidikan bertujuan untuk mengembangkan sumberdaya manusia yang utuh dan handal seharusnya mampu menjadi tempat bersemainya kebaikan. Dimana segala kemampuan dan potensi yang ada dalam diri siswa mampu kembangkan melalui pendidikan. Mendidik dan mempersiapkan siswa untuk mampu hidup sesuai perkembangan zaman diprlukan peran yang sangat handal dari seorang guru. Guru harus mampu mengembangkan segala ranah yang ada dalam diri siswa termasuk ranah berpikir.

Membekali siswa dengan kemampuan berpikir kritis sama halnya dengan membiasakan mereka untuk selalu mengaplikasikan pengetahuan yang dimiliki dalam kehidupan sehari-hari dan memperhatikan perubahan yang ada pada kehidupan. Melihat tujuan dari berpikir kritis yaitu untuk mencapai pemahaman yang mendalam. Pemahaman membuat kita mengerti maksud di balik ide yang mengarahkan hidup kita setiap hari. Kemampuan yang dibutuhkan pada masa mendatang bukan hanya sekedar mengetahui dan memahami suatu hal tetapi kemampuan untuk mampu mengaplikasikan pengetahuan yang dimiliki dalam memecahkan masalah yang dihadapi pada konteks kehidupan sehari-hari. Untuk itu, dalam melaksanakan pembelajaran guru harus mampu menerapkan metode dan model 
yang tepat dalam mengembangkan kemampuan siswa terutama dalam kemampuan berpikir.

Salah satu alternatif model pembelajaran yang dapat diwujudkan dalam pembelajaran IPA adalah model pembelajaran berbasis penemuan (discovery). Menurut Sani (2014:220) discovery adalah penemuan konsep melalui rangkaian data atau informasi yang diperoleh melalui pengamatan atau percobaan. Kegiatan belajar mengajar menggunakan discovery mirip dengan inkuiri (inquiry).Sedangkan Sund dalam Roestiyah (2008: 20) discovery adalah proses mental dimana siswa mampu mengasimilasikan sesuatu konsep atau prinsip. Proses pembelajarannya menekankan pada pembelajaran pengalaman langsung untuk mengembangkan kompetensi agar menjelajahi dan memahami alam sekitar secara ilmiah Melalui discovery learning siswa dapat mengkontruksikan pengetahuan mereka sendiri dengan menemukan sendiri, menyelidiki sendiri, maka hasil yang diperoleh akan setia dan tahan lama dalam ingatan, tidak mudah dilupakan siswa.

\section{METODE PENELITIAN}

Metode penelitian yang digunakan dalam penelitian ini adalah kuasi eksperimen,dengan desainnonequivalent control group design. Menurut Sugiyono (2015: 107) metode penelitian eksperimen merupakan metode yang digunakan untuk mencari pengaruh perlakuan tertentu terhadap yang lain dalam kondisi yang terkendalikan. Penelitian ini menggunakan dua kelas yaitu kelas eksperimen dan kelas kontrol. Kelas eksperimen diberikan perlakuan berupa model discovey learning, sedangkan kelas kontrol tidak diberi perlakuan.

Pengambilan sampel dilakukan dengan teknik sampling jenuh yang merupakan bagian dari nonprobability sampling. Pada teknik ini, seluruh populasi diambil sebagai sampel penelitian. Populasi yang diambil adalah siswa kelas IV SDN Kalisari 03, dengan sampel 26 siswa kelas IVa dan 26 siswa kelas IVb.

Instrument penelitian yang digunakan adalah tes. Tes digunakan untuk mengetahui kemampuan berpikir kritis siswa sebelum (pretest) dan sesudah 
(posttest) diberi perlakuan. Soal yang diberikan berada pada tataran aspek kognitif C3 hingga C6 Taksonomi Bloom. Sebelum diberikan, soal terlebih dahulu diuji cobakan kepada siswa kelas VIb dengan jumlah 24 siswa untuk mengetahui validitas, reliabilitas, daya pembeda dan tingkat kesukarannya.

Teknik analisis data yang digunakan adalah teknik statistika, karena data yang diolah dalam penelitian ini berupa angka.Teknik analisis statistika yang digunakan adalah statistika deskriptif dan statistika inferensial. Data yang dianalisis adalah data nilai pretest dan posttest.

Analisis data dilakukan pada data awal dan akhir. Analisis data awal dilakukan untuk menguji kenormalan homogenitas dan kesamaan varian suatu data yakni data pretest. Analisis data akhir yakni data posttestdilakukan untuk menjawab hipotesis yang telah dirumuskan. Hopotesis tersebut berkenaan dengan kemampuan berpikir kritis siswa dengan menggunakan model discovery learning. Materi tes difokuskan pada muatan pembelajaran IPA dengan materi

\section{HASIL PENELITIAN DAN}

PEMBAHASAN

Penelitian kuantitatif dengan metode eksperimen ini, dilakukan dengan memberikan pretest, treatment dan diakhiri dengan posttest kepada siswa. Pretest diberikan untuk mengetahui kemampuan awal siswa. Pengaruh dari model discovery learning terhadap kemampuan berpikir kritis siswa dapat diketahui melalui posttest.

Berdasarkan hasil penelitian dan pengolahan data hasil pretest dan posttest didapatkan data yang dianalisis menggunakan rata-rata selisih. Dari analisis tersebut diketahui bahwa dari kedua kelas yaitu kelas eksperimen dan kelas kontrolrata-rata selisih antara pretest dan nilai posttest kelas eksperimen 5,19 sedangkan kelas kontrol 3,57. Hal ini menunjukkan rata-rata selisih kelas eksperimen lebih tinggi daripada kelas kontrol.

Dari kedua kelas tersebut nilai selisih yang didapat menunjukkan seberapa besar perbedaan antara nilai pretest dan posttest yang di dapat. Pada kelas kontrol dengan selisih 3,57 menunjukkan bahwa antara pretest dan 
posttest mengalami perubahan sebesar 3,57 dimana dari rata-rata 68.769meningkat menjadi 72.346 . sedangkan untuk kelas eksperimen selisih yang terjadi yakni sebedar 5,19 namus, nilai pretest ke posttest menunjukkan angka yang mengalami penurunan yakni dari rata-rata 72.84 menjadi67.44

Setelah diterapkannya model discovery learning peneliti dapat mengukur kemampuan berpikir kritis siswa melalui posttest. Hal ini dilakukan dengan melihatnilai rata-rata yang mencapai KKM yang telah ditentukan yakni 65. Dari data nilai posttest kelas eksperimen dilihat bahwa rata-rata nilai yang didapat adalah 66.38 yang dapat dkategorikan melampaui KKM. Hal ini menunjukkan bahwa dengan menggunakan model discovery learning di dalam pembelajaran, dapat membuat siswa mencapai KKM yang telah ditentukan.

Berdasarkan hasil analisis data yang telah dilakukan, untuk pengujian hipotesis menggunakan uji ketuntasan menggunakan SPSS versi 22. Hasil output pertama SPSS versi 22, menunjukkan hasil bahwa banyaknya data 25 siswa dengan rata-rata 67,44 dan simpangan baku $=13,16$. Pada output kedua, didapatkan Test Value $=65$ dengan nilai thitung $=0,927$, nilai Sig (2tailed) $=0,363$. Menilik kriteria pengujian hipoteisis dimana jika nilai Sig (2-tailed) $>\alpha$ maka Ho diterima. Hal ini mengandung arti bahwa rata-rata kemampuan berpikir kritis IPA pada mata pelajaran IPA menggunakan model pembelajaran discovery learning mencapai kriteria minimal.

Menerapkan model berbasis penemuan (discovery learning) dapat mengembangkan kemampuan berpikir kritis siswa. Dilihat dari analisis hasil tes yang menggunakan soal pada tingkatan C3 hingga C6 taksonomi Bloom model pembelajaran discovery learning mampu mencapai kriteria minimal. Dengan demikian, model pembelajaran berbasis penemuan ini dapat dijadikan sebagai alternative model pembelajaran dalam mengembangkan berpikir kritis. 


\section{SIMPULAN}

Berdasarkan hasil analisis data dan pembahasan, maka dapat ditarik simpulan bahwa rata-rata kemampuan berpikir kritis IPA pada mata pelajaran IPA menggunakan model pembelajaran discovery learning mencapai kriteria minimal. Hal ini dapat dilihat dari Sig (2tailed) $0,363>0.05$ yang menjadikan hipotesis diterima.

Dari penelitian ini, diharapkan model discovery learning dapat dijadikan sebagai alternatif yang dapat diterapkan di dalam pembelajaran yang inovatif. Peran guru sangatlah diharapkan untuk membimbing siswa dalam proses pembelajaran yang bermakna dalam mengontruksikan pengetahuan yang mereka miliki. Model discovery learaning membuat siswa menjadi pembelajar aktif dimana aktivitas siswa lebih dominan tampak dan hasil belajar siswa lebih baik dibandingkan dengan menggunakan pembelajaran konvensional.

\section{DAFTAR PUSTAKA}

Faiz, F. 2012. Thingking Skills Pengantar Menuju Berfikir Kritis. Yogyakarta: Suka Press

Hosnan, M. 2014. Pendekatan Saintifik dan Kontekstual dalam Pembelajaran Abad 21, Bogor: Ghalia Indonesia

Lestari, E.K dan Yudhanegara, R.M (2015) Penelitian Pendidikan Matematika. Bandung:PT. Refika Aditama

Sani, A. R. 2014. Inovasi Pembelajaran. Jakarta: PT Bumi Aksara

Sugioyono, 2015. Metode Penelitian Pendidikan Pendekatan Kuantitatif, Kualitatif, $R \& D$. Alfabeta: Bandung Suryabrata,S. $2014 . \quad$ Psikologi Pendidikan. Jakarta: Rajawali Pers Trianto,(2015). Model Pembelajaran Terpadu (Konsep, Strategi, dan Implementasinya dalam Kurikulum Tingkat Satuan Pendidikan), Jakarta: PT Bumi Aksara. 